\title{
Preparing for E-Government: some findings and lessons from government agencies in Oyo State, Nigeria
}

\author{
Mutawakilu A. Tiamiyu' \\ Africa Regional Centre for Information Science, University of Ibadan, Nigeria \\ mutatiamiyu@yahoo.com \\ Kemi Ogunsola ${ }^{2}$ \\ Africa Regional Centre for Information Science, University of Ibadan, Nigeria \\ olukemill@yahoo.com
}

\begin{abstract}
Received 12 ${ }^{\text {th }}$ August 2007
Accepted: $31^{\text {st }}$ March 2008

E-government, which entails use of information and communication technologies (ICT) to drive different government processes, promises diverse benefits to governments and citizens. Governments need to understand e-government adequately in order to invest profitably in it, and that can be promoted through studies that assess the development of prerequisite conditions for e-government in government agencies. This study therefore assessed the preparedness for egovernment by Oyo State government agencies in 2006. Data were collected from 134 public servants in 20 of the 45 state agencies. The study found that public servants were motivated to embrace e-government innovations less by citizens' desire for participation and information access; that they viewed e-government more in terms of improving interunit coordination than saving costs or reducing corruption; that the capacities of agencies in respect of electronic systems for capturing, processing and disseminating information to citizens was weak; and that there were no e-government plans in the state or in individual agencies. The study recommended programmes to enlighten governments, citizens and public servants on e-government; e-government strategies and plans to build networks, databases and websites; and support by all stakeholders for a freedom of information law for the country.
\end{abstract}

Key words: e-government, e-administration, ICT, preparedness, Nigeria

\section{Introduction}

Transactions between governments and citizens traditionally took place in physical offices. However, the growing mindset worldwide today is how government agencies can use information and communication technologies (ICT) to improve their efficiencies and deliver services to citizens. This mindset arises from the increasing recognition by policy makers and researchers, of the high correlation and possible causal relationship between the socio-economic development of societies, and growth in the use of ICT, efficient and transparent governance systems, and effective citizen participation in socio-political and economic affairs. Such use of ICT by government is termed electronic government (e-government), a concept defined and explained by the United Nations Department of Economic and Social Affairs - UNDESA (2005) as:

'the application of information and communication technology ... within public administration to optimise its internal and external functions, [thereby providing] government, the citizen and business with a set of tools that can potentially transform the way in which interactions take place, services are delivered, knowledge is utilized, policy is developed and implemented, citizens participate in governance, and public administration reform and good governance goals are met.'

This definition emphasizes the interrelated aspects of e-government - the use of ICT for improving the internal processes of government, and for interacting and transacting business between governments and citizens. But there is as yet no consensus in the literature on a precise definition of e-government. Although the UNDESA definition is embraced by some studies (e.g. Kovacic 2005; Jansen 2005), others adopt definitions that only emphasize the web presence of government agencies in terms of the quality of their websites for delivering information to, transacting business with, or promoting participation in governmental decision-making by, citizens (e.g. Accenture 2004; West 2007). Yet, others like Sheridan and Riley (2006), contrast e-government with e-governance. They explain that e-government relates to the use of ICT to drive both the internal processes of government and external transactions with citizens (which is similar to the internal processes and external transactions aspects of the UNDESA definition), but that e-governance relates to the use of ICT to facilitate social governance processes or objectives such as information dissemination, political participation, consultation and consensus seeking among governments, public servants, politicians and citizens (which relates only to the citizen participation in governance aspects of the UNDESA definition).

I. Muta Tiamiyu, PhD, is an Associate Professor, Africa Regional Centre for Information Science, University of Ibadan Nigeria

2. Kemi Ogunsola is an Assistant lecturer, Africa Regional Centre for Information Science, University of Ibadan, Nigeria. 
Jansen (2005), in line with UNDESA's definitional perspective, outlines the following three interconnected dimensions of e-government: e-administration, which focuses on enhancing management and control within government agencies; eservice, which focuses on the provision of information and services to citizens and businesses; and e-democracy, which focuses on supporting the engagement of civil society in political processes. These three dimensions are interconnected because, ultimately, factors associated with one of them influence and are influenced by factors associated with the others. For instance, e-service sophistication presupposes efficient e-administration, and neither e-administration nor eservice can be effectively provided if government administrative systems are fundamentally outdated or defective. Also, the absence of democratic or participative cultural values and practices in a country may limit motivations among government agencies, politicians and citizens to use ICT, or to initiate or use e-administration, e-service and e-democracy systems (Kovacic 2005).

E-readiness, e-government readiness and e-government maturity are concepts usually discussed in connection with egovernment. E-readiness measures how well a society is positioned to utilize the opportunities provided by ICT for economic and social development (Ojo, Janowski and Estevez 2005). E-readiness therefore pertains to the overall level of society's capability to participate in and benefit from the global digital society. One well known e-readiness index is the Networked Readiness Index, which itself comprises three component indices measuring, respectively, the environment for ICT offered by a given country or community, the readiness of the community's key stakeholders (individuals, businesses, government, etc) to use ICT, and the usage of ICT among these stakeholders (Dutta and Jain 2005). Among the numerous other models and measures of e-readiness is that proposed by Al-Omari and Al-Omari (2006), which suggests that e-readiness should be measured in terms of six dimensions - organizational, governance and leadership, customer, competency, technology, and legal.

E-government readiness assesses how well government agencies and citizens are positioned to use ICT to provide or access e-government services. E-government readiness indices therefore usually focus on variables that measure the ICT infrastructure and human capabilities available to government and citizens, as well as the enabling nature of socioeconomic and politico-legal developments and conditions. E-government maturity, as defined by Accenture (2004), refers to the level to which a government has actually developed an online presence, in contrast to the government's potential to develop such presence. E-government maturity indices focus therefore on the range and sophistication of online services actually being provided by governments through their websites.

\section{Problem statement}

UNDESA's definition of e-government quoted above, as well as those of the other e-government concepts, shows that the feasibility of e-government depends on the availability and accessibility of reliable computer and telecommunication networks to government agencies, citizens and businesses for government interactions and transactions. In 2003 however, Nigeria ranked a low $79^{\text {th }}$ on the 'Networked Readiness Index out of 102 countries surveyed in the Global Information Technology Report (2004). Rankings on the index is based on variables pertaining to "Environment for ICT", "Readiness of key stakeholders to benefit from ICT", and "Level of usage of ICT". Although the country's ranking is very low globally, it ranked lower than only South Africa $\left(37^{\text {th }}\right)$, Tunisia $\left(40^{\text {th }}\right)$, Botswana $\left(55^{\text {th }}\right)$, Namibia $\left(59^{\text {th }}\right)$, Morocco $\left(64^{\text {th }}\right)$, Egypt $\left(65^{\text {th }}\right)$ and Ghana $\left(74^{\text {th }}\right)$ among African countries.

Nigeria's low ranking globally on the index should not surprise, as the country only seriously began to grow its ICT infrastructure after 2000. Both broadcasting and telephone infrastructures and services were provided only by inefficient government monopolies empowered by mostly outdated laws until 1992 when both the National Broadcasting Commissi on (NBC) and the Nigerian Communication Commission (NCC) were established to regulate, license and monitor broadcasting and telecommunications services respectively. But the operational independence of both commissions was severely limited by the military dictatorial polity under which they functioned until 1999. Since 1999, the Nigerian government has repeatedly emphasised its commitment to implement public service reforms using ICT to drive transformations in all its agencies (See, for instance, Obasanjo, 2004).

A Daily Sun (2004) report on e-government challenges in Nigeria published about the same time as the above cited Global Information Technology Report observed however that government transactions at all levels in Nigeria were still characterised by widespread inefficiency, non consumer-centred services, high-level fragmentation and duplication of records, low public accessibility to government information, corruption and lack of transparency, and a large percentage of unproductive clerks and administrators engaged in routine jobs that ICT would have done easily and more efficiently. The Daily Sun report signposts the great challenges ahead of Nigerian governments at the different levels in their efforts to use ICT to transform government processes and services. But, the report does not provide information about specific progress or programmes that individual Nigerian governments or government agencies at the federal, state and local levels are making towards developing, or at least laying the policy and infrastructural foundations for, e-government

SA JnI Libs \& Info Sci 2008, 74(I) 
services. Repeated searches for related literature by this study also could not find any published studies on progress toward the provision of e-government services at the sub-national or agency levels in Nigeria. Accordingly, this study was motivated by the need to contribute to filling this gap in knowledge on e-government preparedness of government agencies in the country.

E-government preparedness surveys generally aim to investigate one or more of the following e-government enabling conditions: ( 1 ) compelling reasons for the government to develop and implement e-government (2) ability of the government to initiate and sustain e-government (3) compelling reasons for the public to utilize e-government (4) ability of the public to begin and continue to utilize e-government" (UNDESA 2005). This study focused on the first two conditions, which are described by such variables as: the perceptions of e-government and of government-citizen relationships and expectations within government agencies; ability and willingness of government to fund e-government projects; availability of relevant ICT infrastructure and human capital in the agencies; use of ICT to drive government business processes; and the nature of government ICT and e-government policies and strategies. Accordingly, the following specific objectives were set for this study:

I. Assess the understanding by the public servants of the nature, opportunities and requirements of e-government systems and services.

2. Identify the potential motivators for the government and public servants to use e-government to improve the internal operations of the agencies and/or to improve government-citizen relationships and services in the state.

3. Assess the e-government capabilities of the agencies in terms of the ICT equipment and infrastructure being used, and ICT human resource development programmes.

4. Assess the nature of the records management, data banking and information processing and dissemination practices in the agencies.

5. Assess the nature of e-government - related policies, plans or initiatives in the state.

6. Recommend how best the government, as well as other stakeholders in e-government could support, provide or use e-government services in the country.

\section{Literature review}

\subsection{Perspectives on e-government and e-governance}

Kettl (2002) has observed that government provides a societal superstructure for politics, policies and programmes, and the quality of government acquires new characteristics when this superstructure is put online. These characteristics include electronic workflow and systems for promoting higher productivity of government operations; automated data processing and integrated data repositories that store and provide access to data sets for programme planning, budgeting and policy research and electronic service delivery, which entails access by citizens and businesses to government documents, information and services.

Riley (2003) additionally emphasizes the role of governance in shaping the mindset of citizens towards social governance which, in the context of e-government, is characterized by electronic engagement of members of the public in the policy process via ICT, such as electronic networks, e-mail, document repository, chat rooms, etc. Such use of ICT opens new channels for citizens to participate in government, thereby bringing government and citizens closer. It is in the same connection that Steven Clift, as cited by Riley (2003), defines the concept of e-democracy as representing the convergence of democratic processes and Internet technology, and as comprising ICT-mediated activities that strengthen the democratic processes by facilitating information access, interaction and policy consultations between governments and citizens.

E-government systems are, in addition to fostering e-administration, expected to facilitate government-citizen services and interactions at three main levels: information provision, transactions, and policy consultation.

(a) Information provision: A distinguishing feature of modern democracies is open debate of issues and periodic free and fair election of political representatives by citizens. Citizens however need current, accurate and timely information about government processes in order to understand, participate in, monitor and control such processes through their participation and votes. Moreover, 'information [access and flow between government and citizens] ... is an essential part of good government. Bad government needs secrecy to survive, [and secrecy] allows inefficiency, wastefulness and corruption to thrive' (Puddephatt 1999).

It is in these contexts that the Internet is now increasingly being used to facilitate access by citizens to government information through email, websites, online reports, mailing lists, online consultations and discussion, chats, etc. Access to government information is also enabled by appropriate national freedom of information (FOI) legislation to compel the disclosure and dissemination of such information to citizens by governments and their agencies. Many developed and developing countries, including Canada, Sweden, USA, UK and South Africa, but excluding Nigeria, have already enacted 
FOI legislation, and more and more countries are also mounting government websites and online portals with cross agency links and directories. Clift (2002), as cited by Riley (2003), reports that in Australia for instance, (http:// www.fed.gov.au) is the federal portal, which is linked to the site for state governments (http://www.gov.au), which, in turn, is linked to the parliament website. There is also a site that combines both state and federal government resources (http:/ /austrialia.gov.au).

(b) Transactions: Governments in developed countries have moved beyond using their websites to provide information only, as they also use them to provide government services to their citizens (Riley, 2003). This enables citizens to exchange transactional data and information on government services thereby removing time and distance barriers to citizens' access to such services. Such services include enabling the downloading and completion of forms online, lodging complaints, voting, paying for services through e-payment systems, etc. E-voting services, for instance, entails such services as online voter registration and online voting during elections or referenda. However, in order for governments to be able to do such real-time transactions with citizens on the web, their agencies have to develop and use appropriate e-commerce applications networked to adequately sophisticated government transactional databases. This in turn implies effective computerization, networking and management of the transactional data and records of the agencies.

(c) Policy consultations: Riley (2003) also describe online policy consultation as the use of ICT to obtain input from citizens into government policies and initiatives. Online policy consultation includes either sporadic or intensive communication between citizens and government officials and agencies on plans, budgets, bills and policies, for which different types of electronic technologies may be used, including email, video conferences, radio or TV programmes, websites, e-kiosk, etc. Such consultations make policy and law makers readily accessible and accountable to their electorate or publics, thereby placing real legislative and policy making power more and more in the hands of citizens (Nyamnjoh, 2005). Online consultation focuses on special events or special topics with specific start and closing dates. Riley (2003) reports that in Sweden, for instance, the Kalix City Council conducted an experiment in online deliberation, which allowed the citizens to have online discussions with local politicians, by giving their opinion on the renovation of the town hall. Participation was through the Internet, and other traditional means such as the telephone and fax. Citizens also voted on issues online, and many voters reported the experience as a valuable democratic initiative.

\subsection{E-government maturity}

As explained earlier, e-government maturity refers to the level to which a government has actually developed an online presence (Accenture, 2004). The concept of e-government maturity focuses on the actual end-products of e-government projects, i.e., the types and quality of e-government services provided through government websites and portals. Different e-government maturity models and assessment indices have been proposed, and they invariably outline the different stages of e-government maturity in terms of types, levels and sophistication of provided services, as well as how the level of sophistication of the services may be used to assess the level of e-government maturity of a country or government agency. An assumption underlying e-government maturity models and indices is that the availability of an egovernment service through a website implies that the inputs, infrastructure, policies and processes required to make the services available on the website are available, optimal and sustainable. Such assumption might not always be wise.

The range of possible e-government services discussed above attests to the potential benefits that countries would derive from growing their national ICT infrastructure to enable e-government. Nevertheless, the development and use of ICT infrastructure nationally is but only one aspect of the requirements for providing sustainable e-government services. In this regard, UNDESA (2005) reports that as many as between $60-80 \%$ e-government projects fail as a result of inadequate attention to the different critical factors for success, including objectives, infrastructure, legislation and regulatory environment, organizational and back-office reengineering, human resources, among others. Other challenging requirements include the understanding and acceptance by governments, public servants and citizens of egovernment innovations, replacement of traditional government information processes with efficient e-government systems, and the motivation and skill of public servants to use the systems to deliver new government services to citizens. It is in this connection that Estevez, Janowski and Ojo (2007) emphasize the need to adequately study, understand, model and plan agency-level goals, inputs (infrastructure, human resources, etc), processes (intra- and inter-agency relationships and interactions), and outputs (e-government services) of a government agency in order to develop successful egovernment information systems and websites for providing e-government services.

As highlighted by Jansen (2005) and discussed earlier, e-government comprises three main interconnected aspects - eadministration, e-service, and e-democracy. Most e-maturity surveys focus on the e-service and e-democracy aspects which can easily be determined by browsing the websites of government agencies. Clearly, a necessary complementary approach to assessing progress toward e-government overall, particularly in developing countries, is to investigate e-

SA Jnl Libs \& Info Sci 2008, 74(I) 
government from the e-administration aspect to find out if conditions and developments at that end are being tuned appropriately to provide the foundation for the e-service and e-democracy aspects of e-government. Computerizing the internal and external processes of public agencies is of course a key aspect of e-administration, but whether such computerization is being directed by e-service and e-democracy objectives is another matter altogether. It is from that perspective that this study sought to investigate the perceptions and expectations of e-government within some of the public agencies of Oyo State of Nigeria, as well as the preparedness for e-government of existing operational practices, ICT infrastructure and plans of the agencies.

\subsection{E-government initiatives in Africa}

South Africa is much ahead of other sub-Saharan African countries in the exploitation of ICT for e-government. Mutula (2002), for instance, reports that during the 1999 parliamentary and presidential elections in South Africa, voters registration, as well as the polling process, including the relaying and verification of ballots throughout the country were aided by ICT, including satellite-enabled wide area network (WAN), fax machines and telephones. He also noted that the process was largely successful, as the electoral process was expeditious and was accepted by the great majority of the people as transparent, free and fair.

The 200I UN benchmark survey of global e-government (UN-DPEPA 2002) which focused primarily on website availability, content and services put Africa's regional e-government readiness index at 0.84 (compare with 3.11 for the USA), with only the following countries exceeding the regional average: South Africa (I.56), Djibouti (I.35), Gabon (1.17), Cote D'Ivoire (1.05), Nigeria (I.02), Cameroon (0.99), Ghana (0.98), the Central African Republic (0.98), Congo (0.94), Mauritania (0.9I) and Kenya (0.90). Accordingly, Ronaghan (2002) concludes that Africa's e-government capacity is generally deficient compared to other regions of the world because of the near-total absence of the core areas necessary to sustain an enabling e-government environment. But despite the region's lack of adequate telecommunications infrastructure, nearly all sub-Saharan countries have some forms of web presence, although most African countries offer only static information websites.

\subsection{E-readiness and e-government initiatives in Nigeria}

In Nigeria, a number of significant e-government initiatives, policies and projects began as from 2000, but these efforts are related more to the government's desire to develop national and governmental ICT infrastructures and possibly facilitate some internal e-government processes than to provide citizen-oriented e-government services. In furtherance of this desire, the National Communications Commission (NCC) was reconstituted and strengthened by new statute, and the Federal Ministry of Science and Technology drew up the National Policy on Information Technology (IT Policy) in 200I, and established the National Information and Technology Development Agency (NITDA), the agency charged with coordinating the implementation of the policy. A major aspect of NITDA's activities since then has been awareness creation and government ICT infrastructure and human capacity building.

The IT policy seeks to integrate ICT into various national sectors to ensure improved economy and help the country take initiatives to address socio-economic issues, such as reliable infrastructure, skilled human resources, open government and other essential issues of capacity building (NITDA 200I). From the specific perspective of egovernment, the policy emphasizes the following imperatives:

- Infrastructure: (i) Establish and develop a National Information Infrastructure (NII), connecting it with state information infrastructure (SII) and the Local Information Infrastructure (LII). (ii) Ratify a Data Protection Act (DPA) for safeguarding the privacy of national computerised records and electronic documents. (iii) Ensure the implementation of compatible standards for the networking of all government organisations to share data, information and reporting online, and establish interagency structures.

- Human resource development: Make information technology (IT) mandatory at all levels of educational institutions, to develop relevant IT curricula for the primary, secondary and tertiary institutions, implement a virtual digital library scheme, establish facilities for electronic distance learning networks, empower IT institutions and development centres to develop IT capacities, etc.

- Governance: (i) Use IT as the major driving force to transform governance to interface with the needs of its citizenry by establishing transparent "government-wide information system (GWIS)" at national, state and local government levels. (ii) Expand skill and career development of information technology professionals in government, and make IT skill acquisition mandatory for all government employees. (iii) Establish Internet connectivity and access for government employees at all levels, and establish websites for improved government image and as information centres for the citizenry (iv) Simplify citizens' access to the process of governance and government information by providing choices and options for interaction with government, and advance the use of electronic media for government contract tendering and procurement processes. 
These policy initiatives, as well as the specific projects that have been or are being implemented through them, highlight the Nigerian federal government's efforts to develop the national information technology infrastructure and human resource base for the country. However, in the federal system of government that Nigeria operates, it should be clear that federal efforts can only lay the backbone of the national information technology infrastructure, but not the state and local level networks and government services required by citizens at the grassroots. State and local governments need to complement federal initiatives. And it is from this perspective that this study sought to investigate what state governments and agencies have been doing towards e-government.

\section{Methodology}

3.1 Public agencies and servants of the state

Oyo state of Nigeria was chosen for this study because it is one of the oldest states in the country. The state government had a total workforce of 32,385 in 2004, distributed across the Office of the State Governor, the Legislature, the Judiciary, ministries and parastatals. The work force comprised II,762 civil servants, 14,603 teachers, 2656 employees of parastatals, and 3,284 employees of state-owned higher institutions (Oyo State, 2005).

\subsection{Population and sampling}

A survey research design was used in the study. The survey aimed to sample only from the population of senior civil servants in the ministries and parastatals, totalling 7035. Sampling for the questionnaire survey was at two levels - agency and respondent, and with purposive sampling being used at both levels.

At the agency level, Oyo State had 15 ministries and 30 parastatals at the time of the study, and 20 of them ( 10 from each of the two categories of agencies) were sampled, constituting $44.4 \%$ of the agencies. The purposive sampling technique was used to select the following 10 largest (identified through total numbers of employees) ministries: Education; Science and Technology; Information and Culture; Finance, Budget and Planning; Women Affairs, Community Development and Social Welfare; Works and Transport; Justice; Establishment, Training and Poverty Alleviation; Agriculture, National Resources and Rural Development; Land and Housing. Similarly, purposive sampling was also used to select the following 10 largest parastatals: Ibadan Solid Waste Management Authority; Water Corporation of Oyo State; State Universal Basic Education Board; Auditor-General (Local Government); Auditor-General (State Government); Broadcasting Corporation of Oyo State (BCOS); Post-Primary Schools Teaching Service Commission; Oyo State Management Information Centre; Oyo State Printing Press; Oyo State Hospital Management Board.

At the respondent level, the survey targeted the same set of seven (7) purposively selected management and senior staff of each sampled agency, comprising: (i) Director of Planning, Research, and Statistics; (ii) Assistant Director of Planning, Research, and Statistics; (iii) Head of the Records Registry; (iv) one Computer Analyst/Data Processing Officer; (v) one administrative officer, (vi) one accounting officer, and (vii) one confidential secretary. This purposive sampling was in order to ensure (a) roughly equal representation of each agency in the sample, (b) representation in the sample of a senior staff from the personnel, finance, research, IT, information and record management departments of each agency (c) a sample comprising staff that are likely to be knowledgeable and/or be involved in e-government plans or projects (if any) of the government.

\subsection{Data collection and analyses}

A questionnaire was the main data collection method used. The e-government readiness assessment methodology and questionnaire (UNDESA, 2003, 2005) provided the bulk of the items in the questionnaire. The questionnaire data were complemented with information obtained from an interview with the head of the Oyo State Management Information Centre (MIC). A total of 140 copies of the questionnaires were administered in the 20 sampled agencies, out of which I34 copies were returned completed. The questionnaire data were analysed with the aid of the Statistical Package for Social Sciences (SPSS). Data analyses comprised frequencies and descriptive statistics, complemented with the Friedman non-parametric mean rank tests.

The Friedman non-parametric mean rank test compares related variables in terms of the data collected on them. Data collected on most of the variables through the questionnaire were in the form of 'strongly agree', 'agree', 'neither agree nor disagree', 'disagree' or 'strongly disagree' responses, which were coded 5, 4, 3, 2 and I respectively for the analyses. Such ordinal level data are best analysed with non-parametric statistical methods (Connover 1980:60-66). The Friedman test initially assigns ranks to each of the different responses received by each of the set of related variables being compared (e.g. the level of perceived availability of different types of ICT in a government agency). Thereafter, the Friedman test calculates and compares the average (mean) rank of the responses received by the variables to determine if the calculated mean ranks are significantly different from one another. Significant differences (at the $5 \%$ level) among at least some of the mean ranks imply that the variables were not rated equally by the respondents. In this study, in view of 
the way that the responses were coded for the analyses, variables that got higher Friedman mean ranks received more 'strongly agree' and 'agree' responses from the respondents compared to other variables, whereas the variables that got lesser mean ranks received more 'strongly disagree' and 'disagree' responses than the others.

\section{Findings and discussion}

The data analyses and findings are presented and discussed hereunder in terms of the first five objectives of the study. The sixth objective pertains to recommendations, which are presented later.

\section{Objective I: Assess the understanding by the public servants of the nature, opportunities and requirements of e-government systems and services.}

4.1 Public servants perceptions of citizens' expectations of governance

Table I summarizes the ratings by the sampled public servants of citizens' expectations of the purposes of governance in the state. Rated most highly were citizens' expectations of governance services pertaining to 'education', 'social welfare', 'agriculture and environment', and 'health'. These expectations are essentially output-oriented, and are followed, with only slightly lower ratings, by such process-oriented expectations as 'increased opportunity for participation in policymaking and implementation', 'transparency and accountability', 'friendliness and attentiveness', and 'responsiveness'. Very worrying however, is the very low rating of 'access to (government) information'. It is worrying because e-government maturity indicators agree that providing government information, and facilitating citizens' access to such information, is the entry level e-government service that governments can readily provide through email and websites. This finding also suggests inadequate eagerness by citizens for involvement in government decision-making and control processes, and/or inadequate sensing of such desires by public servants, and/or inadequate appreciation by both citizens and public servants of the importance of citizens' access to government information as means for promoting social inclusion, political participation and economic empowerment for citizens.

Table I Public servants' perceptions of citizens' expectations of governance

\begin{tabular}{|c|c|c|c|c|}
\hline Expectation of ... & \begin{tabular}{|l|} 
Low \\
$\%$
\end{tabular} & $\begin{array}{l}\text { Medium } \\
\% \\
\end{array}$ & \begin{tabular}{|l|} 
High \\
$\%$ \\
\end{tabular} & $\begin{array}{l}\text { Friedman } \\
\text { Mean Rank }\end{array}$ \\
\hline Services related to Education & 9.3 & 21.7 & 69.0 & 3.90 \\
\hline Services related to Social welfare & 14.5 & 21.4 & 64.1 & 3.73 \\
\hline Services related to Agriculture/Environment & 11.5 & 26.7 & 61.8 & 3.73 \\
\hline Services related to Health & 15.7 & 23.1 & 61.2 & 3.63 \\
\hline Increased opportunity for participation in policy making and implementation & 12.3 & 31.3 & 56.5 & 3.60 \\
\hline Transparency and accountability & 18.6 & 25.4 & 56.0 & 3.57 \\
\hline Friendliness and attentiveness & 15.5 & 32.6 & 52.0 & 3.57 \\
\hline Responsiveness & 16.7 & 29.5 & 53.8 & 3.53 \\
\hline High quality of service & 18.9 & 25.0 & 56.1 & 3.52 \\
\hline Visible impact of feedback (especially in politics) & 21.0 & 30.8 & 48.1 & 3.42 \\
\hline Services related to: economic development and opportunities (trade, employment, SMEs) & 19.4 & 34.9 & 45.7 & 3.41 \\
\hline Access to information & 23.7 & 21.4 & 54.9 & 3.41 \\
\hline Government efforts to bridge the Digital Divide & 29.9 & 21.3 & 48.8 & 3.26 \\
\hline Citizen centred (life-cycle) services & 25.6 & 31.8 & 42.7 & 3.23 \\
\hline
\end{tabular}

$\mathrm{N}=134$

\subsection{Awareness of e-government and its potential benefits}

E-government and e-governance are news items in the Nigerian media. The study however did not take understanding of e-government among public servants for granted, and therefore investigated the level of awareness of the nature, benefits and requirements of e-government among the sampled public servants. Table 2 shows that senior-level managers are the most aware, followed by the top policy-makers. Middle-level and other (junior-level) public servants were not as much aware. These patterns are probably explained by the fact that e-government systems are not yet operational in most agencies, which makes operational-level managers (i.e. the middle-level managers and others) to be less aware of its characteristics. Moreover, e-government and e-governance are likely to be included as topics in policy-oriented 
workshops for top policy-makers and senior public servants, and less likely to be included in practical ICT training for lower-level public servants.

Table 2 Awareness of the benefits of e-government among different categories of public servants

\begin{tabular}{|l|l|l|l|l|l|l|}
\hline Category & $\begin{array}{l}\text { Very Poor } \\
\%\end{array}$ & $\begin{array}{l}\text { Poor } \\
\%\end{array}$ & $\begin{array}{l}\text { Good } \\
\%\end{array}$ & $\begin{array}{l}\text { Very Good } \\
\%\end{array}$ & $\begin{array}{l}\text { Excellent } \\
\%\end{array}$ & $\begin{array}{l}\text { Friedman } \\
\text { Mean Rank }\end{array}$ \\
\hline Senior-level managers & 7.6 & 17.6 & 40.5 & 26.0 & 8.4 & 3.10 \\
\hline Top policy makers & 5.5 & 22.7 & 41.4 & 21.0 & 9.4 & 3.06 \\
\hline Middle-level managers & 6.2 & 21.5 & 46.9 & 20.8 & 4.6 & 2.96 \\
\hline Other civil servants & 10.9 & 36.7 & 35.9 & 14.1 & 2.3 & 2.60 \\
\hline
\end{tabular}

$\mathrm{N}=134$

\section{Objective 2: Identify the potential motivators for the government and public servants to use e- government to improve the internal and external operations.}

4.3 Motivators for using e-Government to improve internal operations of government

Table 3 shows that among the potential motivators to use e-government to improve the internal operations of the public agencies, inter-departmental coordination and cooperation was rated highest, followed by 'improving efficiency and effectiveness', 'internal communication', 'record-keeping, searching and archiving data'. Lower down in the ratings were 'improving information base for decision making', 'cost savings', and 'increased public safety'. Much lower still in the ratings were such considerations as 'prevent corruption', 'increase government flexibility', and 'having integrated information systems'. Such relative rankings for the different motivators suggest that the public servants were more aware of the potentials of e-government systems to help improve the inter-unit coordination and cooperation that would arise from better internal communication and record-keeping, but much less in terms of cost savings, corruption control, greater flexibility and speed of operations, and improvement in overall knowledge management for decision-making.

Table 3 Motivators for using e-governance systems to improve the internal operations of government agencies

\begin{tabular}{|l|l|l|l|l|}
\hline Motivating factors for internal government operations & $\begin{array}{l}\text { Low } \\
\%\end{array}$ & $\begin{array}{l}\text { Medium } \\
\%\end{array}$ & $\begin{array}{l}\text { High } \\
\%\end{array}$ & $\begin{array}{l}\text { Friedman } \\
\text { Mean Rank }\end{array}$ \\
\hline Inter-departmental coordination and cooperation & 6.0 & 32.3 & 61.7 & 3.77 \\
\hline Improving efficiency and effectiveness & 18.3 & 25.0 & 56.8 & 3.56 \\
\hline Internal communication (information flows) & 12.9 & 31.1 & 56.1 & 3.55 \\
\hline Record-keeping, search and archiving data & 16.0 & 33.6 & 50.4 & 3.52 \\
\hline Improving information base for decision making & 16.8 & 40.5 & 42.7 & 3.37 \\
\hline Cost savings & 20.6 & 39.7 & 39.7 & 3.30 \\
\hline Increase public safety & 23.3 & 32.3 & 44.3 & 3.29 \\
\hline Improving communication between the political and administrative process & 19.5 & 43.6 & 36.9 & 3.23 \\
\hline Freedom of Information & 21.8 & 39.8 & 38.4 & 3.22 \\
\hline Prevent corruption & 23.8 & 36.2 & 40.0 & 3.22 \\
\hline Increase government flexibility & 22.1 & 39.7 & 38.1 & 3.18 \\
\hline Having integrated information systems & 30.7 & 35.4 & 33.8 & 3.03 \\
\hline Alignment with international or regional standards or cooperation frameworks & 33.9 & 33.1 & 33.1 & 3.02 \\
\hline
\end{tabular}

$\mathrm{N}=134$

4.4 Motivators to use e-government to improve government-citizen relationships.

What factors were most likely to motivate public servants in desiring to use e-government systems to enhance the relations between government and citizens? Table 4 shows that in the purview of the public servants, the most important potentially motivating factors for building and using e-government systems in the state were related to government's responsibilities in 'education' and 'environmental regulation' (not surprising in view of the ratings of these social services sectors in Table I), and 'economic development'. Noticeable however, is the higher relative rating here of using egovernment for supporting 'government's responsibility for economic development' compared to the much lower relative rating in Table I of citizens' expectation of governance to provide 'Services related to: economic development and opportunities (trade, employment, SMEs)'. It would appear therefore that the public servants saw e-government systems

SA Jnl Libs \& Info Sci 2008, 74(I) 
mostly as tools for assisting government's internal planning and decision-making for providing social and economic services, rather than for the direct provision of government information to, or interaction with, citizens.

The high ratings of education, environmental regulation and economic development in Table 4 were followed by the ratings for 'improving public revenue flows' and 'efficiency and effectiveness'. Surprisingly, citizen-oriented motivators for using e-government to improve government-citizen relationships were rated relatively lower, including such motivations as 'community empowerment', 'improving client satisfaction', 'stimulating citizens awareness, win public trust and generate interest in e-government', 'provide access to information', 'transparency and accountability', and 'citizen participation'. These ratings also support our earlier conclusion that the public servants viewed ICT in government more in e-administration terms (such as to improve the effectiveness and efficiency of government agencies, revenue generation, provide educational and economic opportunities and regulate the environment), and much less in e-service or e-democracy terms (such as to increase citizens' awareness of, or participation in, government activities).

Table 4 Motivators for using e-governance to improve relationships between government and citizens

\begin{tabular}{|c|c|c|c|c|}
\hline Motivating factor & $\begin{array}{l}\text { Low } \\
\%\end{array}$ & $\begin{array}{l}\text { Medium } \\
\%\end{array}$ & $\begin{array}{l}\text { High } \\
\%\end{array}$ & $\begin{array}{l}\text { Friedman } \\
\text { Mean Rank }\end{array}$ \\
\hline $\begin{array}{l}\text { Government responsibility in education (generating and harvesting creativity and knowledge } \\
\text { to enhance the population's quality of life) }\end{array}$ & 23.2 & 30.1 & 57.2 & 3.65 \\
\hline Government responsibility in economic development & 13.6 & 34.6 & 51.9 & 3.53 \\
\hline Government responsibility for environmental regulation & 14.3 & 34.6 & 51.1 & 3.48 \\
\hline Improving public revenue flows (e.g. enhanced ability to collect revenue) & 17.9 & 31.3 & 50.7 & 3.47 \\
\hline Efficiency and effectiveness & 12.8 & 39.1 & 48.1 & 3.46 \\
\hline Government responsibility in community empowerment & 16.0 & 37.4 & 46.6 & 3.43 \\
\hline Inter-departmental coordination and cooperation & 12.3 & 40.8 & 47.0 & 3.43 \\
\hline Improving client satisfaction & 18.5 & 37.7 & 43.8 & 3.32 \\
\hline The need to be "cost competitive" & 19.3 & 36.9 & 43.9 & 3.32 \\
\hline Stimulate citizen's awareness, win public trust and generate interest in e-government & 22.5 & 33.1 & 44.3 & 3.31 \\
\hline Provide access to information & 21.2 & 39.4 & 39.4 & 3.24 \\
\hline Transparency and accountability & 25.4 & 32.1 & 42.6 & 3.24 \\
\hline Citizen participation & 21.0 & 42.1 & 36.9 & 3.21 \\
\hline Government responsibility in international trade & 28.6 & 35.3 & 36.1 & 3.08 \\
\hline Alignment with international or regional standards or cooperation frameworks & 25.0 & 43.2 & 31.8 & 3.08 \\
\hline Government responsibility for reducing social exclusion and marginalization & 25.4 & 45.4 & 29.2 & 3.06 \\
\hline Donor pressure and availability of grant funding (loans) to pursue certain programmes & 31.0 & 35.7 & 33.3 & 3.04 \\
\hline Generate and provide locally relevant content on the Internet & 42.8 & 29.3 & 27.9 & 2.78 \\
\hline Government responsibility to diminish the digital divide & 39.9 & 40.6 & 19.5 & 2.73 \\
\hline
\end{tabular}

$\mathrm{N}=134$

4.5 Features of government-citizen relationships and services.

Also examined was public servants' perceptions of the features of existing government-citizen relationships and services in the state which serve to describe the environment in which e-government systems and services could be developed. Table 5 shows that less than $50 \%$ of the sampled public servants agreed that citizen-centred initiatives of government are common (46\%), that government offices respond timely and efficiently to dealing with citizens (31\%), and that agencies provide special access facilities for vulnerable members of society $(4 / \%)$. In other words, the sampled public servants acknowledged that government to citizen initiatives and services were mostly not citizen-centred (evidenced by the lowest rating accorded to 'citizen-centred services' in Table I), not timely, and largely uncaring for the special needs of disadvantaged groups in society. These findings indicate that the subsisting paradigm for the provision of government services by the agencies tend to run against a key philosophy of e-government, which is to improve access to, and participation in government information, transactions and policy making by all citizens, and particularly by the disadvantaged groups in society. 
Table 5 Characteristics of existing government-citizen relationships

\begin{tabular}{|l|l|l|l|}
\hline Characteristic & $\begin{array}{l}\text { Yes } \\
\%\end{array}$ & $\begin{array}{l}\text { No } \\
\%\end{array}$ & $\begin{array}{l}\text { Don't Know } \\
\%\end{array}$ \\
\hline Initiatives of citizen-centred government are common and widely used by public agencies & 46.4 & 31.2 & 22.4 \\
\hline $\begin{array}{l}\text { The time factor in dealings between members of the civil society and government offices is not } \\
\text { important because government offices respond timely and efficiently. }\end{array}$ & 31.0 & 58.1 & 10.9 \\
\hline $\begin{array}{l}\text { Does your agency provide special access to services to vulnerable groups (elderly, disabled) and other } \\
\text { marginalized groups (women, minorities, and children)? }\end{array}$ & 41.4 & 49.2 & 9.4 \\
\hline
\end{tabular}

$\mathrm{N}=134$

\section{Objective 3: Assess the e-government capabilities of the agencies in terms of the ICT equipment, infrastructure and human resources.}

4.6 Availability of ICT equipment

Table 6 provides data on the availability of different ICT equipment in the agencies as reported by the sampled public servants. The Friedman mean ranks for the different equipment in the table show that desktop computers were the most commonly available in the agencies, followed closely by printers, NITEL (land-line) phones, photocopiers, TV sets, PABX (intercom), radio cassette player machines and video players. These basic ICT are more suited to the traditional and mostly manual operations and services, but not for modern e-government systems that require such ICT as Internet connectivity, laptop computers, digital cameras, fax machines, scanners, VSAT terminals, audio conferencing and video conferencing systems. The mean ranks of such sophisticated equipment place them in the bottom half or third of the table.

Table 6 Availability of ICT equipment in the agencies

\begin{tabular}{|c|c|c|c|c|}
\hline Type of Equipment & $\begin{array}{l}\text { No } \\
\%\end{array}$ & $\begin{array}{l}\text { Don't Know } \\
\%\end{array}$ & $\begin{array}{l}\text { Yes } \\
\%\end{array}$ & \begin{tabular}{|l|} 
Friedman \\
Mean Rank
\end{tabular} \\
\hline Desktop computers & 5.5 & 2.4 & 92.1 & 2.87 \\
\hline Printers & 7.6 & 3.8 & 88.5 & 2.81 \\
\hline NITEL (land line) phone & 15.2 & 0.8 & 84.0 & 2.69 \\
\hline Photocopier & 14.3 & 2.4 & 83.3 & 2.69 \\
\hline TV sets & 15.6 & 2.3 & 82.0 & 2.66 \\
\hline PABX (intercom) & 22.0 & 0.8 & 77.2 & 2.55 \\
\hline Radio cassette players & 19.2 & 6.2 & 74.6 & 2.55 \\
\hline Video player & 34.4 & 4.9 & 60.7 & 2.26 \\
\hline \multicolumn{5}{|l|}{ Middle third } \\
\hline Mobile phone & 38.0 & 2.5 & 59.5 & 2.21 \\
\hline DSTV & 42.4 & 7.6 & 50.0 & 2.08 \\
\hline Video recorder & 49.2 & 3.4 & 47.5 & 1.98 \\
\hline Video camera & 53.3 & 2.5 & 44.2 & 1.91 \\
\hline Scanner & 51.3 & 10.3 & 38.5 & 1.87 \\
\hline E-mail & 56.3 & 9.2 & 34.5 & 1.78 \\
\hline Digital camera & 60.5 & 5.3 & 34.2 & 1.74 \\
\hline Fax machine & 58.8 & 12.6 & 28.6 & 1.70 \\
\hline \multicolumn{5}{|l|}{ Bottom third } \\
\hline Editing units & 62.9 & 9.5 & 27.6 & 1.65 \\
\hline Laptop computers & 61.9 & 12.7 & 25.4 & 1.64 \\
\hline World wide web & 68.9 & 7.6 & 23.5 & 1.55 \\
\hline Recording studio & 73.9 & 5.2 & 20.9 & 1.47 \\
\hline V-SAT satellite terminals & 67.2 & 19.8 & 12.9 & 1.46 \\
\hline Audio conferencing & 70.1 & 17.1 & 12.8 & 1.43 \\
\hline Video conferencing & 69.9 & 16.8 & 13.3 & 1.43 \\
\hline Walkie-talkies & 83.2 & 3.5 & 13.3 & 1.30 \\
\hline
\end{tabular}


4.7 Use of ICT and mass communication networks

Data were also collected on the use of the electronic media and other mass media, telecommunications networks and Internet facilities by the agencies for advertising their activities and operations or for exchanging information with external publics, such as citizens or other governmental agencies. Table 7, which summarizes the data shows that traditional mass media (i.e. radio and television and, to a lesser extent, the print media) were used for advertising the services of the agencies as confirmed by $67.2 \%, 57.9 \%$ and $53.4 \%$ of the public servants respectively. However, only $27.3 \%$ of the respondents confirmed that the agencies had e-mail addresses, while only $14 \%$ confirmed that the agencies actually used such addresses in their operations. Finally, although $21.9 \%$ of the respondents confirmed that their agencies had local area networks (LAN), only $7.1 \%$ of them confirmed that there was any form of intranet or digital connectivity between the state and local governments in the state.

Table 7 Use of ICT networks

\begin{tabular}{|c|c|c|c|c|}
\hline & $\begin{array}{l}\text { No } \\
\%\end{array}$ & $\begin{array}{l}\text { Don't Know } \\
\%\end{array}$ & $\begin{array}{l}\text { Yes } \\
\%\end{array}$ & $\begin{array}{l}\text { Friedman } \\
\text { Mean Rank }\end{array}$ \\
\hline \multicolumn{5}{|l|}{ (a) Use of Computer Networks } \\
\hline Is there a government wide LAN/ Intranet? & 53.9 & 24.2 & 21.9 & 1.68 \\
\hline Does your agency have E-mail address? & 61.2 & 11.6 & 27.3 & 1.66 \\
\hline If yes, does your agency use it? & 60.0 & 26.0 & 14.0 & 1.54 \\
\hline $\begin{array}{l}\text { Is there intranet connectivity and digital interaction between the central and local } \\
\text { governments? }\end{array}$ & 69.8 & 23.0 & 7.1 & 1.37 \\
\hline Does your agency have a website address? & 76.0 & 15.5 & 8.5 & 1.33 \\
\hline \multicolumn{5}{|l|}{ (b) Use of Mass Communication Networks } \\
\hline Does your agency advertise any of its services on the Radio? & 28.2 & 4.6 & 67.2 & 2.39 \\
\hline Does your agency advertise any of its services on the Television? & 36.8 & 5.3 & 57.9 & 2.21 \\
\hline Does your agency advertise any of its services in the print media? & 39.8 & 6.8 & 53.4 & 2.14 \\
\hline
\end{tabular}

\subsection{Human resources}

E-government innovations may initially be 'supply pushed' into government by external bodies such as donor agencies and equipment vendors. But the sustainability and growth of such innovations depend on continuing 'demand pull' by governments, government agencies and public servants themselves. In turn, the capacity of public agencies to effectively build and use government information systems depends on the knowledge and skill of their human resources, as well as continuous improvement to that knowledge and skill. Accordingly, the study collected and analyzed data on the recent ICT training exposure and experiences of the sampled public servants. Tables $8 \mathrm{a}$ and $8 \mathrm{~b}$ summarized the data.

Table 8a How often are people in your agency sent for ICT training?

\begin{tabular}{|l|l|}
\hline & $\%$ \\
\hline Never & 18.5 \\
\hline Rarely & 47.7 \\
\hline Often & 28.5 \\
\hline Very often & 5.4 \\
\hline $\mathrm{N}=134$ &
\end{tabular}

Table 8b When last did you attend a training course focusing on the use ICT in your work?

\begin{tabular}{|l|l|}
\hline & $\%$ \\
\hline $1-6$ months ago & 18.3 \\
\hline $7-12$ months ago & 11.9 \\
\hline Greater than I-2 years ago & 8.7 \\
\hline More than 2 years ago & 8.7 \\
\hline Never & 52.4 \\
\hline$N=134$ &
\end{tabular}


Table 8a shows that almost two-thirds (66.2\%) of the sampled public servants claimed that rarely or never had 'people in their agencies' been sponsored 'by their agencies' to attend ICT-related training. Table $8 \mathrm{~b}$ shows further that more than half $(52.4 \%)$ of the sampled public servants themselves had never attended such ICT-related training (sponsored or unsponsored by their agencies), while a further $8.7 \%$ had had such training more than two years before the survey. The data shows that much still needs to be done to improve, through regular ICT-related training, the capacity of public servants in the state agencies to use ICT. Nevertheless, it is also important to bear in mind that a public servant "being computer literate' is different from the public servant knowing and being skilled in how to build and operate efficient egovernment systems and services. The latter demands citizen-centered orientation to the provision of government services (a policy matter), as well as adequate knowledge of the characteristics of ICT for e-government, and awareness of the feasibility of, and strategies for, e-government services in Nigeria's socio-political environment.

\subsection{Capacities of agencies to perform information management activities}

The fourth objective of the study reported under items 4.9 and 4.10 is to assess the nature of the records management, data banking and information processing and dissemination practices in the agencies. The internal capacity of government agencies ICT to perform different information management activities towards providing effective and efficient government services depends, of course, on such variables as baseline information management capacities and cultures, availability of ICT infrastructure, the nature of the cultural, legal and institutional environments, the knowledge and skills of human resources, etc, and the desire and capacity to improve such variables. E-government demands from government agencies the capabilities to use different information technologies to manage government information effectively and efficiently.

In order to assess such capabilities, each of the responding public servants was asked to rate his/her own agency's internal capacity to undertake different information management activities, such as information capture, transformation, storage, retrieval and dissemination. Table 9 summarizes the ratings. Rated highest were the capacities of the agencies to gather information, followed by capacities to produce (i.e. create new), analyze (i.e. by decision-makers) and distribute information internally. Poorly rated, however, were capacities to process or digitize information (by computer), or provide public access to information. These findings show that despite previous efforts to computerize many of the state's agencies, their capacities to manage information were still geared to manual systems for collecting, producing and analyzing information, and were weak in respect of using ICT to capture, digitize or process information internally, or to disseminate information to citizens.

Table 9 Capacity of agencies to perform information management activities effectively and efficiently

\begin{tabular}{|l|l|l|l|l|l|l|}
\hline Information management activity & $\begin{array}{l}\text { Very Poor } \\
\%\end{array}$ & $\begin{array}{l}\text { Poor } \\
\%\end{array}$ & $\begin{array}{l}\text { Good } \\
\%\end{array}$ & $\begin{array}{l}\text { Very Good } \\
\%\end{array}$ & $\begin{array}{l}\text { Excellent } \\
\%\end{array}$ & $\begin{array}{l}\text { Friedman } \\
\text { MeanRank }\end{array}$ \\
\hline Gather information & 2.3 & 7.8 & 34.9 & 45.7 & 9.3 & 3.52 \\
\hline Produce new information & 3.8 & 9.2 & 43.1 & 31.5 & 11.5 & 3.40 \\
\hline Analyse information & 0.8 & 15.4 & 39.2 & 34.6 & 10.0 & 3.38 \\
\hline Distribute information & 1.6 & 13.4 & 41.7 & 33.1 & 10.2 & 3.37 \\
\hline Archive information & 2.3 & 15.4 & 40.8 & 30.0 & 11.5 & 3.33 \\
\hline Process information & 3.1 & 14.8 & 43.0 & 31.3 & 7.8 & 3.26 \\
\hline Give public access to information & 6.2 & 19.2 & 34.6 & 29.2 & 10.8 & 3.19 \\
\hline Digitise information & 8.5 & 34.1 & 32.6 & 19.4 & 5.4 & 2.79 \\
\hline
\end{tabular}

$\mathrm{N}=134$

\subsection{Data and records management practices}

The reported higher availability of micro-computers than other types of ICT equipment in the agencies in Table 6 does not imply automatically that such equipment are adequate, or are effectively being used for the various information management tasks identified in Table 9. In view of the fact that e-government processes depend on the effective and efficient organization, storage and retrieval of information in managed electronic records to support information dissemination and transactions between government and citizens, the study investigated whether and what types of records were being maintained in electronic databases or data banks in the agencies. 
Table 10 Maintenance of Records in a Database or Databank

\begin{tabular}{|l|l|l|l|l|}
\hline Type of Records & $\begin{array}{l}\text { No } \\
\%\end{array}$ & $\begin{array}{l}\text { Don't } \\
\text { Know\% }\end{array}$ & $\begin{array}{l}\text { Yes } \\
\%\end{array}$ & $\begin{array}{l}\text { Friedman } \\
\text { Mean Rank }\end{array}$ \\
\hline Budgets and plans & 28.0 & 10.6 & 61.4 & 2.33 \\
\hline Wages and salaries records & 31.8 & 4.7 & 63.6 & 2.32 \\
\hline Field survey data/statistics & 36.2 & 15.0 & 48.0 & 2.14 \\
\hline Middle third & 43.2 & 5.3 & 50.8 & 2.10 \\
\hline Minutes of meetings records & 41.9 & 7.8 & 50.4 & 2.09 \\
\hline Technical reports & 45.5 & 6.8 & 47.0 & 2.03 \\
\hline Memoranda/circulars & \multicolumn{5}{l}{} \\
\hline Bottom third & 48.9 & 8.4 & 42.7 & 1.94 \\
\hline Personnel records & 50.0 & 8.5 & 415 & 1.92 \\
\hline Correspondence incoming/outgoing) & 57.6 & 8.8 & 33.6 & 1.76 \\
\hline Records of sales/purchases & N=I34 \\
\hline
\end{tabular}

As shown in Table 10, about $60 \%$ of the respondents said their agencies kept budgets and plans, as well as wage and salary records in databases, whereas almost or a little above $50 \%$ of them confirmed that field survey data and statistics, minutes of meetings, technical reports and memoranda/circulars were kept in databases. Lower percentages of them said that personnel records, correspondence and records of sales and purchases were maintained in databases. These percentages confirm the fact that databases and/or computerized files (word processor files, spreadsheets, etc) were being used for storing internal records (except personnel records which were still mostly paper-based), but much less for records pertaining to correspondence and transactions with external publics which were mostly manual and paper-based.

4.11 Institutional strategies for monitoring and evaluation of e-government initiatives

The fifth objective of the study is to assess the nature of e-government-related policies, plans or initiatives in the state. Only $44 \%$ of the respondents said that their agencies had an 'e-government strategy and action plan' (Table II). Respondents who said that there were plans did not however answer the other related questions such as 'Specify how it relates to the national e-government strategy and action plan (if at all)' and 'Attach relevant documentation or provide relevant URL (web page address)'. Non-responses to these follow-up questions probably reflect the public servants' lack of ready access to the requested documents or URLs, or inadequate understanding of their contents. Or, maybe, they just thought the plans existed, because the interview with the head of the Oyo State Management Information Centre (OYMIC) revealed that the agency had no strategy or action plan, and that the entire state had no strategy or action plan.

Table II Monitoring and Evaluation of e-government initiatives

\begin{tabular}{|l|l|l|l|}
\hline & $\begin{array}{l}\text { Yes } \\
\%\end{array}$ & $\begin{array}{l}\text { No } \\
\%\end{array}$ & $\begin{array}{l}\text { Don't Know } \\
\%\end{array}$ \\
\hline $\begin{array}{l}\text { Does an e-government strategy and action plan } \\
\text { exist for your agency or ministry? }\end{array}$ & 44.1 & 49.2 & 9.4 \\
\hline $\begin{array}{l}\text { Is there a provision for Monitoring and Evaluation } \\
\text { of e-government initiatives? }\end{array}$ & 35.7 & 36.5 & 27.8 \\
\hline $\begin{array}{l}\text { Is there a central e-government unit in the } \\
\text { administration? }\end{array}$ & 32.5 & 21.1 & 46.3 \\
\hline
\end{tabular}

$N=134$

Table II shows further that $36 \%$ of the respondents believed that there was 'Provision for monitoring and evaluation of egovernment initiatives' in the state. Information obtained through the interview with the head of OYMIC showed however that there was no special provision for such monitoring and evaluation of e-government initiatives other than the normal processes for the monitoring and evaluation of all government projects. In other words, e-government initiatives did not receive more special or strategic attention than other initiatives of government. This shows that many public servants who affirmed that there was provision for monitoring and evaluation of e-government initiatives either did so based on mere assumption or that they misunderstood government ICT initiatives for e-government focused initiatives. Finally, 
Table II shows that $32.5 \%$ of the public servants confirmed that there was 'a central e-government unit in the administration' of the state, and almost all of such public servants identified the OYMIC as the central unit, when asked. Findings from the interview with the head of OYMIC however showed that the agency itself did not see itself as 'the central e-government unit', because it understood better than others the usual responsibilities of such central egovernment units world-wide, and was also painfully aware of its limited responsibilities and roles in relation to egovernment and e-governance initiatives in the state.

In summary, it appears from Table II that, as at the time of this study, the state government and its agencies were more generally oriented toward promoting the computerization of its agencies based on the traditional management information system (MIS) philosophy (hence, the establishment of OYMIC), and less aware or ready to transform government activities through carefully planned and monitored strategies to use ICT to provide e-government services to citizens.

\section{Recommendations and Conclusion}

This study's sixth and final objective is to make recommendations based on its findings for promoting the development of e-government services in the state and elsewhere. Accordingly, government, public agencies and citizens in the state, Nigeria and other African countries should consider the following when implementing plans for e-government innovations to promote the social development of their societies.

- Governments, their agencies and public servants need to move toward providing more responsive, speedy, transparent and citizen-centred services to their publics. They should advertise the different aspects of their services, respond quickly to citizens' demands for their services, and promote citizens' participation in policy formulation through the electronic media and online, thereby laying the foundations for e-government services.

- Public servants need to gear or be geared up, to perform more effectively their roles and responsibilities in ensuring that government agencies provide responsive, speedy, transparent and citizen-centred services that recognize the special needs of disadvantaged groups.

- Governments need to develop appropriate e-government visions and plans to guide computerization programmes and projects in their agencies. Such strategies and plans should aim for effective change management in order to replace traditional government processes and services with those enabled by efficient e-government systems. The plans should include phased provisions for databases, LANs, data communication backbones, Internet-connectivity and databasedriven websites. Also required are pilot e-government systems and services involving selected agencies, in order to gradually improve public servants' and citizens' understanding of the nature, requirements and benefits of such services. The plans should also provide for recruiting and training public servants for the e-administration, e-service and edemocracy dimensions of e-government. Such training should incorporate appropriate content, evaluation, feedback and follow-up strategies to ensure that the trained public servants are adequately skilled and geared up build, operate and sustain efficient e-government systems and services.

- All stakeholders in good and corruption-free governance in Nigeria - governments, citizens, the civil society, business, international community, etc - should support vigorously the enactment into law of the Freedom of Information bill (FOI) presently in the National Assembly. This is in view of the potential role of e-government systems in promoting efficient, transparent and participatory governance, and the mutually-supporting character of e-government systems and Freedom of Information (FOI) legislation. The FOI law will clearly expand the scope for citizens' legal access to government information and impose legal obligations on public servants to implement programmes and projects to provide or enable access to citizen-centred government information and services.

- Citizens need more enlightenment, as well as legal assistance when necessary, on when and how to demand for their rights of access to government information under existing statutes, and under the FOl bill when it is passed into law. In conclusion, it is important to reiterate some of the potential benefits of e-government systems and services to governments and citizens, including increased efficiency, transparency and citizens' access to government processes and services. Such systems and services would also help to grow the nascent democratic governance culture in Nigeria because of the increased communication and interaction between citizens and government that they would foster. Governance in any society is a process that evolves over time, and public understanding and participation in democratic governance in Nigeria, as well as in e-government systems, can and should be accelerated through appropriate social policies, enlightenment programmes, action plans and other initiatives by the different stakeholders in good governance for national development. Such initiatives should aim to promote public discussion and action on such e-government issues as potential opportunities and challenges in using e-government systems to promote democratic good governance in the country, strategies for improving the capacities of governments to provide e-government systems and services, and strategies for improving the capacities of citizens, and particularly the illiterate and disadvantaged groups, to demand, access and use such systems and services.

SA Jnl Libs \& Info Sci 2008, 74(I) 


\section{References}

Accenture 2004, E-government leadership: high performance, maximum value. Retrieved September 2, 2006, from http:// www.accenture.com/NR/rdonlyres/D7206199-C3D4-4CB4-A7D8-846C94287890/0/gove_egov_value.pdf

Al-Omari, A \& Al-Omari, H 2006, 'E-government readiness assessment model', Journal of Computer Science, vol. 2, no. II, pp. $84 I-45$

Clift S 2002, E-governance to e-democracy: progress in Australia and New Zealand towards information-age democracy. Retrieved on December 12, 2005, from http://www.publicus.net

Connover, W. J. 1980. Practical nonparametric statistics. New York: Wiley.

Daily Sun 2004, 'Nigeria sets agenda for e-government implementation', 29 March. Retrieved on April 10, 2005, from http:// www.sunnewsonline.com/webpages/features/cybersun/2005/feb/07/cybersun-07-02-2005-003.htm

Dutta, S \& Jain, A 2005, The networked readiness index, 2003-2004: overview and analysis framework. Fontainebleau, France: INSEAD.

Estevez, E, Janowski, T \& Ojo, A 2007, Planning for e-government - a service-oriented agency survey, UNU-IIST Report No. 36I, April, I5p.

Global information technology report 2003-2004: towards an equitable information society 2004, Paris: InfoDev, World Economic Forum \& INSEAD. Retrieved on December 20, 2006, from http://www.infodev.org/en/Publication. I5.html

Ifinedo, P 2006, 'Towards e-government in a sub-Saharan African country: impediments and initiatives in Nigeria', Journal of E-Government, vol. 3, no. I, pp. 3-28.

Jansen, A 2005, 'Assessing e-government progress - why and what?', Paper presented at NOKOBIT 2005 Conference, 2I-23 November, Bergen, in B.J. Iden og G. Christensen (red), NOKOBIT, 2005.

Kettl, D 2002, The transformation of governance: public administration for the 2/st century, Baltimore: Johns Hopkins University Press.

Kovacic, Z 2005, 'The impact of national culture on worldwide e-government readiness', Informing Science Journal, vol. 8, pp. 143-158.

Mutula, SM 2002, Supporting democracy with ICTs: South Africa's Independent Electoral Commission - e-government for development success/failure case study No. 2, University of Manchester, Institute for Development Policy and Management. Retrieved April 14, 2005, from www.egov4dev.org/iec.htm

NITDA 200I, Nigerian National Policy for Information Technology 200I, National Information Technology Development Agency, Nigeria. Retrieved on December 12, 2006, from www.uneca.org/aisi/nici/Documents/IT\%20policy\%20for\%20Nigeria.pdf).

Nyamnjoh, FB 2005, Africa's media: democracy and the politics of belonging, London, Zed Books.

Obasanjo, O. 2004. Speech presented at the stakeholders conference on national egovernment strategies and implementation for Nigeria, Abuja. Retrieved on December 10, 2005, from http://www.nigeriafirst.org/objspeeches/2004/ stakeholders_conf.html).

Ojo, A, Janowski, T \& Estevez, E 2005, 'Determining progress towards e-government: what are the core indicators', in D. Remenyi (ed), Proceedings of the $5^{\text {th }}$ European conference on e-government, University of Antwerp, Belgium, 6-1 7 June.

Oyo State 2005, 'First anniversary programme of events, 2004', Oyo State 2005 Dairy, Ministry of Information and Culture, Oyo State, Nigeria.

Puddephatt, A 1999, 'Preface' in The public's right to know: principles on freedom of information legislation (International standards series, Article 19), London. Retrieved on March 7, 2007, from http://www.arabaccess.org/archives/Article\%2019.PDF)

Riley, TB 2003, E-government vs. E-governance: Examining the differences in a changing public sector climate, International Tracking Survey Report, No. 4, Commonwealth Secretariat. (Retrieved on December 15, 2006, from www.rileyis.com/publications/ research_papers/tracking03/Int/TrackRptMay03no4.pdf)

Riley TB \& Riley CG 2003, E-governance to E-democracy: Examining the evolution. (International Tracking Survey Report, No. 5, Commonwealth Secretariat. Retrieved on November 15, 2005, from http://www.electronicgov.net

Ronaghan, S 2002, Benchmarking e-government: a global perspective - assessing the progress of the UN member states, New York, United Nations DPEPA. Retrieved on December 12, 2006, from http://www.unpanl.un.org/intradoc/groups/public/ documents/UN/UNPAN02 1547.pdf)

Sheridan, W and Riley, TB 2006, Comparing e-government and e-governance. Retrieved on December 12, 2006, from http:// www.electronicgov.net/pubs/research_papers/SheridanRileyComparEgov.doc).

UNDESA 2003, E-government readiness assessment survey - agencies section. Retrieved on April 14, 2005, from http:// unpan I.un.org/intradoc/groups/public/documents/un/unpan0II5II.pdf).

UNDESA 2005, E-government readiness assessment methodology. Retrieved on February 6, 2006, from http://www.unpan.org/ dpepa-kmb-eg-egovranda-ready.asp

UN-DPEPA 2002, Benchmarking e-government - a global perspective: assessing the Progress of the UN member states. United Nations - Division for Public Economics and Public Administration. Retrieved on December 12, 2007 from http:// www.unpan I.un.org/intradoc/groups/public/documents/UN/UNPAN02 I547.pdf)

West, DM 2007, Global E-Government, 2007, Centre for Public Policy, Brown University. Retrieved on November 3, 2008 from http://www.insidepolitics.org/egovt07int.pdf 